\title{
PENGARUH LATIHAN DENGAN PEMBERIAN JUS PSIDIUM GUAJAVA TERHADAP KOMPONEN FISIK PREDOMINAN (DAYA TAHAN JANTUNG, PARU, KEKUATAN OTOT, DAYA LEDAK OTOT, KECEPATAN REAKSI, KELINCAHAN, DAYA TAHAN OTOT, DAN KELENTUKAN) ATLET YONG MOODO PADA PERSIAPAN PERTANDINGAN ANTAR BATALYON
}

\author{
R. Bayu Kusumah $\mathbf{N}$ \\ Program Studi Diploma Tiga Keperawatan \\ byu_aleeya@stikesdhb.ac.id
}

\begin{abstract}
ABSTRAK
Upaya pembinaan prestasi atlet di lingkungan Angkatan Darat, khususnya Cabang Olahraga Yong Moodo, sedang diupayakan oleh Panglima Angkatan Darat agar beprestasi pada event regional maupun internasional. Komponen fisik predominan pada atlet Yong Moodo agar berprestasi adalah: daya tahan jantung paru, kekuatan otot, daya ledak otot, kecepatan reaksi, kelincahan, daya tahan otot, dan kelentukan.. Untuk mengeliminasi peningkatan radikal bebas dengan pemberian buah-buahan yang mengandung antioksidan, misalnya psidium guajava (jambu biji merah). Buah jambu biji merah mengandung antioksidan, berupa: vitamin $C, \beta$-karoten, vitamin E, selenium, copper, zinc, likopen, lutein (astaxantin), xantin, ellagic acid, anthozyanidin, quercetin, lignin. Dilakukan penelitian pengaruh pemberian jus psidium guajava terhadap komponen fisik predominan pada persiapan pertandingan antar batalyon.

Metode penelitian adalah eksperimen di lapangan dilanjutkan pemeriksaan darah di laboratorium. Subjek penelitian Anggota TNI AD YON-ARMED 7/105 GS Bekasi Jawa Barat sebanyak 14 orang, dibagi dua kelompok secara acak. kelompok A (diberi latihan selama 6 minggu dengan pemberian Jus Jambu Biji Merah) sebanyak 7 orang, kelompok B (diberi latihan selama 6 minggu tanpa diberi jus Jambu Biji Merah) sebanyak 7 orang sebagai kelompok kontrol. Data hasil penelitian dianalisis menggunakan uji normalitas data dengan Kolmogorov-Smirnov, uji homogenitas varians menurut levene, t-test, F-Manova untuk mengetahui pengaruh pemberian jus psidium guajava terhadap komponen fisik predominan.

Terdapat peningkatan daya tahan jantung paru, kekuatan otot lengan kanan, lengan kiri, kekuatan menarik, kekuatan mendorong, kekuatan otot pinggang, kekuatan otot tungkai, daya tahan otot perut, otot lengan, daya ledak otot lengan, otot tungkai, kelincahan, kelentukan, kecepatan reaksi.

Latihan selama 6 minggu dengan pemberian jus psidium guajava dapat meningkatkan komponen fisik predominan atlet Yong Moodo Yon Armed 7/105 Bekasi.
\end{abstract}

Kata Kunci : Atlet Yong Moodo, latihan, komponen fisik predominan

\section{PENDAHULUAN}

Upaya pembinaan prestasi atlet di

lingkungan Angkatan Darat, khususnya

Cabang Olahraga Yong Moodo, sedang

diupayakan oleh Panglima Angkatan Darat

agar dapat beprestasi pada event regional

maupun internasional. Atlet dari berbagai cabang olahraga, antara lain Atlet Yong Moodo sedang dipersiapkan oleh masingmasing batalyon diseluruh Indonesia dalam rangka persiapan menghadapi Pekan Olahraga Angkatan Darat (PORAD). Untuk meningkatkan prestasi atlet memerlukan 
pembinaan dengan menerapkan IPTEK olahraga pada program periodisasi latihan ${ }^{1}$.

program periodisasi latihan terdiri dari tahap persiapan (tahap persiapan umum dan tahap persiapan khusus), tahap pertandingan (tahap pra pertandingan dan tahap pertandingan utama), dan tahap transisi ${ }^{2,3}$. Mengamati pola gerak cabang olahraga Yong Moodo, komponen fisik predominan pada atlet Yong Moodo yang kemampuannya perlu dimaksimalkan agar dapat berprestasi adalah: daya tahan jantung paru, kekuatan otot, daya ledak otot, kecepatan reaksi, kelincahan, daya tahan otot, dan kelentukan ${ }^{3}$.

Berdasarkan pola gerak atlet Yong Moodo yang banyak melakukan teknik pukulan, tendangan, tangkisan, kuncian dan bantingan maka sumber energi pada atlet Yong Moodo berasal dari metabolisme aerobik dan metabolisme anaerobik ${ }^{6}$. Oleh karena gerakan atlet Yong Moodo dilakukan dengan intensitas tinggi pada suasana aerobik memungkinkan terbentuknya oksidan. Sampai saat ini belum diketahui dengan jelas seberapa besar pengaruh latihan terhadap perubahan kadar oksidan pada tubuh atlet Yong Moodo. Proses terbentuknya oksidan pada atlet Yong Moodo terjadi pada saat latihan oleh karena meningkatnya kebutuhan oksigen. Pada saat aktivitas intensitas tinggi tersebut terjadi kebocoran oksigen sehingga terbentuk oksidan. Pembentukan oksidan terjadi oleh karena oksigen yang dikonsumsi sel tidak semuanya dapat direduksi secara sempurna, sebagian mengalami kebocoran pada tahap tertentu dari transpor elektron dan kemudian keluar jalur respirasi yang berubah menjadi oksidan ${ }^{7}$.

Pembentukan oksidan pada suasana aerobik berbeda dengan pada saat atlet melakukan gerakan anaerobik. Gerakan anaerobik pada saat latihan yang dilakukan atlet cabang olahraga Yong Moodo, yaitu pada saat melakukan gerakan pukulan, tendangan, tangkisan, kuncian dan bantingan. Pada saat melakukan gerakan tersebut terjadi proses referpusi yang menyebabkan terbentuknya oksidan yang dapat berupa reactive oxygen species (ROS) atau Radikal bebas.

Peningkatan radikal bebas akan menyebabkan gangguan dan bahkan dapat menyebabkan kerusakan mitokondria. Akibat terganggunya fungsi mitokondria maka terganggu pula pembentukan energi ATP yang diperlukan atlet Yong Moodo pada saat latihan ataupun pertandingan. Keadaan ini kemungkinan dapat mempengaruhi prestasi atlet Yong Moodo ${ }^{11}$.

Akhir-akhir ini berbagai upaya dilakukan untuk mengeliminasi peningkatan radikal bebas antara lain dengan pemberian buahbuahan yang mengandung antioksidan, misalnya psidium guajava (jambu biji merah). Buah jambu biji merah mengandung antioksidan, berupa: vitamin $\mathrm{C}, \beta$-karoten, vitamin E, selenium, copper, zinc, likopen, lutein (astaxantin), xantin, ellagic acid, anthozyanidin, quercetin, lignin. Lignin yang 
memiliki potensi anti inflamasi dan antioksidan 15 .

Untuk mengetahui ada tidaknya pengaruh latihan dan pemberian jus Jambu Biji Merah terhadap komponen fisik predominan atlet Yong Moodo (daya tahan jantung paru, kekuatan otot, daya ledak otot, kecepatan reaksi, kelincahan, daya tahan otot, dan kelentukan) dan kadar NO, dapat dilakukan dengan pengukuran sebagai berikut: kecepatan reaksi diukur dengan time reactions, kelincahan diukur dengan beam side step, daya tahan jantung paru diukur dengan harvard step test, daya tahan otot perut diukur dengan situps, daya tahan otot lengan dan bahu diukur dengan push-up, daya tahan otot tungkai diukur dengan squat-jumps, kelentukan diukur dengan flexometer metode sit and reach test, daya ledak otot tungkai diukur dengan vertical jumps, daya ledak otot tangan diukur dengan medicine ball, kekuatan otot lengan diukur dengan hand dynamometer, kekuatan otot punggung diukur dengan back dynamometer, kekuatan otot tungkai diukur dengan leg dynamometer. ${ }^{15}$

\section{METODE PENELITIAN}

Rancangan penelitian adalah metode eksperimen yang dilakukan di lapangan dan dilanjutkan dengan pemeriksaan darah di laboratorium.

Subjek penelitian berasal dari Anggota TNI AD YON-ARMED 7/105 GS Bekasi Jawa Barat sebanyak 14 orang, yang dibagi dalam dua kelompok secara acak, yaitu kelompok A (yang diberi latihan selama 6 minggu dengan pemberian Jus Jambu Biji Merah) sebanyak 7 orang dan kelompok B (yang diberi latihan selama 6 minggu tanpa diberi jus Jambu Biji Merah) sebanyak 7 orang sebagai kelompok kontrol. Data hasil penelitian dianalisis menggunakan uji normalitas data dengan Kolmogorov-Smirnov, uji homogenitas varians menurut levene, t-test, F-Manova untuk mengetahui pengaruh pemberian jus psidium guajava terhadap komponen fisik predominan.

\section{HASIL DAN PEMBAHASAN}

\section{Karakteristik Fisikfisiologis Subjek Penelitian}

Tabel 4.1. Karakteristik Fisikfisiologis Subjek Penelitian

\begin{tabular}{|c|c|c|c|c|}
\hline \multirow{3}{*}{$\begin{array}{c}\text { Karakteristik Fisik } \\
\text { Fisiologis }\end{array}$} & \multicolumn{4}{|c|}{ Kelompok } \\
\hline & \multicolumn{2}{|c|}{$\mathrm{A}$} & \multicolumn{2}{|c|}{ B } \\
\hline & $\overline{8}$ & $\mathrm{Sd}$ & $\overline{\mathrm{B}}$ & $\mathrm{Sd}$ \\
\hline Umur & 24.57 & 1.90 & 24.71 & 1.80 \\
\hline Berat Badan & 69.29 & 5.91 & 66.57 & 5.74 \\
\hline Tinggi Badan & 169.00 & 3.37 & 169.71 & 3.86 \\
\hline Indeks Massa Tubuh & 24.29 & 1.70 & 23.14 & 1.87 \\
\hline Nadi Istirahat & 73.14 & 10.82 & 72.00 & 7.21 \\
\hline Sistole & 103.57 & 11.80 & 108.57 & 8.99 \\
\hline Diastole & 66.43 & 7.48 & 70.71 & 9.32 \\
\hline
\end{tabular}




\section{Kemampuan Komponen Fisik Kelompok A dan Kelompok B sebelum dilakukan Perlakuan}

Tabel 4.2 Kemampuan Komponen Fisik Kelompok A dan Kelompok B sebelum dilakukan Perlakuan

\begin{tabular}{|c|c|c|c|c|c|}
\hline \multirow{3}{*}{ Karakteristik Fisik } & \multicolumn{4}{|c|}{ Kelompok } & \multirow{3}{*}{$\begin{array}{c}\mathrm{P} \\
\text { value }\end{array}$} \\
\hline & \multicolumn{2}{|c|}{$\mathrm{A}$} & \multicolumn{2}{|c|}{ B } & \\
\hline & $\overline{\bar{z}}$ & $\mathrm{sd}$ & 5 & $\mathrm{Sd}$ & \\
\hline \multicolumn{6}{|l|}{ Strength: } \\
\hline Hand Grip Kanan Pre & 45.36 & 4.10 & 48.41 & 4.34 & 0.201 \\
\hline Hand Grip Kiri Pre & 42.74 & 4.49 & 43.97 & 3.82 & 0.592 \\
\hline Pull Pre & 35.36 & 8.55 & 34.93 & 5.26 & 0.912 \\
\hline Push Pre & 34.64 & 13.90 & 36.71 & 12.86 & 0.777 \\
\hline Back Pre & 111.43 & 13.56 & 116.36 & 16.62 & 0.555 \\
\hline Leg Pre & 185.60 & 32.60 & 219.07 & 34.19 & 0.085 \\
\hline VO2 Max Pre & 45.57 & 5.59 & 46.86 & 6.39 & 0.696 \\
\hline \multicolumn{6}{|l|}{ Daya Ledak Otot: } \\
\hline Vertical Jump Pre & 59.00 & 8.87 & 59.71 & 9.95 & 0.890 \\
\hline Medicine Ball Pre & 426.43 & 49.56 & 438.57 & 56.95 & 0.678 \\
\hline \multicolumn{6}{|l|}{ Dava Tahan Otot: } \\
\hline Push Up Pre & 40.43 & 5.53 & 41.43 & 8.40 & 0.797 \\
\hline Sit Up Pre & 35.57 & 6.63 & 32.29 & 3.59 & 0.271 \\
\hline Flexibility Pre & 20.29 & 4.95 & 19.50 & 4.92 & 0.771 \\
\hline Agility Pre & 24.86 & 3.34 & 25.00 & 4.28 & 0.234 \\
\hline Speed Reaction Pre & 210.68 & 20.23 & 233.86 & 60.19 & 0.353 \\
\hline Nitric Oxide Pre & 17.50 & 6.53 & 9.67 & 3.63 & 0.017 \\
\hline
\end{tabular}

3. Pengaruh latihan dan pemberian jus Psidium Guajava pada Kelompok A terhadap kemampuan fisik predominan pada atlet Yong Moodo.

Tabel 3 Pengaruh latihan dan pemberian jus Psidium Guajava pada Kelompok A terhadap kemampuan fisik predominan pada atlet Yong Moodo.

\begin{tabular}{|c|c|c|c|c|c|c|c|}
\hline \multirow{2}{*}{$\begin{array}{c}\text { Kemampuan Fisik } \\
\text { Predominan }\end{array}$} & \multicolumn{2}{|c|}{ Pre-test } & \multicolumn{2}{|c|}{ Post-test } & \multirow{2}{*}{$\mathrm{t}$} & \multirow{2}{*}{$\begin{array}{c}\mathrm{P} \\
\text { Value }\end{array}$} & \multirow{2}{*}{$\begin{array}{c}\text { Besar } \\
\text { Pengaruh }\end{array}$} \\
\hline & $\overline{8}$ & $\mathrm{sd}$ & $\bar{z}$ & sd & & & \\
\hline Hand Grip Kanan & 45.36 & 4.10 & 55.34 & 5.02 & -4.074 & 0.002 & $18.05 \%$ \\
\hline Hand Grip Kiri & 42.74 & 4.49 & 51.72 & 5.44 & -3.369 & 0.006 & $17.38 \%$ \\
\hline Pull & 35.36 & 8.55 & 44.29 & 10.75 & -1.720 & 0.111 & $20.16 \%$ \\
\hline Push & 34.64 & 13.90 & 43.43 & 17.53 & -1.040 & 0.319 & $20.24 \%$ \\
\hline Back & 111.43 & 13.56 & 142.07 & 17.29 & -3.690 & 0.003 & $21.57 \%$ \\
\hline Leg & 185.60 & 32.60 & 241.30 & 42.37 & -2.757 & 0.017 & $23.08 \%$ \\
\hline VO2 max & 45.57 & 5.59 & 55.42 & 6.71 & -2.987 & 0.011 & $17.79 \%$ \\
\hline Vertical Jump & 59.00 & 8.87 & 68.57 & 10.25 & -1.869 & 0.086 & $13.96 \%$ \\
\hline Medicine Ball & 426.43 & 49.56 & 530.86 & 61.80 & -3.488 & 0.004 & $19.67 \%$ \\
\hline Speed Reaction & 210.68 & 20.23 & 162.23 & 15.57 & 5.021 & 0.000 & $-23.00 \%$ \\
\hline Push Up & 40.43 & 5.53 & 51.14 & 7.01 & -3.174 & 0.008 & $20.94 \%$ \\
\hline Sit Up & 35.57 & 6.63 & 47.43 & 9.03 & -2.800 & 0.016 & $24.98 \%$ \\
\hline Flexibility & 20.29 & 4.95 & 25.21 & 6.16 & -1.650 & 0.125 & $19.56 \%$ \\
\hline Agility & 22.71 & 2.21 & 26.57 & 2.51 & -3.051 & 0.010 & $-14.53 \%$ \\
\hline
\end{tabular}


4. Pengaruh latihan pada kelompok B terhadap kemampuan fisik predominan pada atlet Yong Moodo

Tabel 4 Pengaruh latihan pada kelompok B terhadap kemampuan fisik predominan pada atlet Yong Moodo

\begin{tabular}{|c|c|c|c|c|c|c|c|}
\hline \multirow{2}{*}{$\begin{array}{l}\text { Kemampuan Fisik } \\
\text { Predominan }\end{array}$} & \multicolumn{2}{|c|}{ Pre-test } & \multicolumn{2}{|c|}{ Post-test } & \multirow{2}{*}{$\mathrm{t}$} & \multirow{2}{*}{$\begin{array}{c}\mathrm{p} \\
\text { value }\end{array}$} & \multirow{2}{*}{$\begin{array}{c}\text { Besar } \\
\text { Pengaruh }\end{array}$} \\
\hline & $\bar{\Sigma}$ & $\mathrm{sd}$ & $\bar{s}$ & $\mathrm{sd}$ & & & \\
\hline Hand Grip Kana & 48.41 & 4.34 & 51.44 & 4.61 & -1.266 & 0.230 & $5.89 \%$ \\
\hline Hand Grip Kiri & 43.97 & 3.82 & 46.29 & 4.02 & -1.103 & 0.292 & $5.00 \%$ \\
\hline Pull & 34.93 & 5.26 & 37.29 & 5.77 & -0.799 & 0.440 & $6.32 \%$ \\
\hline Push & 36.71 & 12.85 & 39.43 & 13.75 & -0.382 & 0.709 & $6.88 \%$ \\
\hline Back & 116.36 & 16.62 & 123.29 & 17.66 & -0.800 & 0.440 & $5.95 \%$ \\
\hline Leg & 219.07 & 34.19 & 239.70 & 37.42 & -1.077 & 0.303 & $8.61 \%$ \\
\hline VO2 max & 46.86 & 6.39 & 51.29 & 6.87 & -1.249 & 0.236 & $8.64 \%$ \\
\hline Vertical Jump & 59.71 & 9.95 & 63.29 & 10.44 & -0.655 & 0.525 & $5.64 \%$ \\
\hline Medicine Ball & 438.57 & 56.95 & 470.99 & 61.08 & -1.027 & 0.325 & $6.88 \%$ \\
\hline Speed Reaction & 233.86 & 60.19 & 209.88 & 53.48 & 0.807 & 0.435 & $-10.50 \%$ \\
\hline Push Up & 41.43 & 8.40 & 46.42 & 9.52 & -1.042 & 0.318 & $10.77 \%$ \\
\hline Sit Up & 32.29 & 3.59 & 36.29 & 4.54 & -1.829 & 0.092 & $11.02 \%$ \\
\hline Flexibility & 19.50 & 4.92 & 21.56 & 5.43 & -0.743 & 0.472 & $9.54 \%$ \\
\hline Agility & 25.00 & 4.28 & 27.11 & 4.46 & -0.905 & 0.383 & $-7.80 \%$ \\
\hline
\end{tabular}

5. Perbedaan Pengaruh Perlakuan pada Kelompok A dan Kelompok B Terhadap Kemampuan Fisik Predominan (Kekuatan Otot, Daya Tahan Jantung Paru, Daya Ledak Otot, Daya Tahan Otot, Kelentukan, Kelincahan Dan Kecepatan Reaksi Pada Atlet Yong Moodo Yon Armed 7/105 GS Bekasi

Tabel 5 Perbedaan pengaruh perlakuan pada kelompok A dengan kelompok B terhadap peningkatan Kemampuan Fisik Predominan (kekuatan otot, daya tahan jantung paru, daya ledak otot, daya tahan otot, kelentukan, kelincahan dan kecepatan reaksi)

\begin{tabular}{lcccccc}
\hline \multirow{2}{*}{$\begin{array}{l}\text { Kemampuan Fisik } \\
\text { Predominan }\end{array}$} & \multicolumn{9}{c}{$\mathrm{A}$} & & \multicolumn{2}{c}{ B } & \multirow{2}{*}{$\begin{array}{c}\text { Stat Uji F } \\
\text { Manova }\end{array}$} & $\begin{array}{c}\mathrm{p} \\
\text { value }\end{array}$ \\
\cline { 2 - 5 } & $\overline{\mathrm{z}}$ & $\mathrm{sd}$ & $\bar{\Sigma}$ & $\mathrm{sd}$ & & \\
\hline Hand Grip Kanan & 55.34 & 5.02 & 51.44 & 4.61 & 6.206 & 0.003 \\
\hline Hand Grip Kiri & 51.72 & 5.44 & 46.28 & 4.02 & 5.498 & 0.005 \\
\hline Pull & 44.29 & 10.75 & 37.29 & 5.77 & 2.110 & 0.125 \\
\hline Push & 43.43 & 17.53 & 37.71 & 13.38 & 0.472 & 0.704 \\
\hline Back & 142.07 & 17.29 & 123.69 & 17.66 & 4.721 & 0.010 \\
\hline Leg & 241.30 & 42.37 & 239.70 & 37.42 & 3.471 & 0.032 \\
\hline VO2 Max & 55.42 & 6.71 & 51.29 & 6.87 & 3.433 & 0.033 \\
\hline Vertical Jump & 68.57 & 10.25 & 63.29 & 10.44 & 1.369 & 0.276 \\
\hline Medicine Ball & 530.86 & 61.80 & 470.99 & 61.08 & 4.612 & 0.011 \\
\hline Speed Reaction & 162.23 & 15.57 & 209.30 & 53.49 & 3.544 & 0.030 \\
\hline Push Up & 51.14 & 7.01 & 46.43 & 9.52 & 2.841 & 0.059 \\
\hline Sit Up & 47.43 & 9.03 & 36.29 & 4.54 & 7.649 & 0.001 \\
\hline Flexibility & 25.21 & 6.16 & 21.56 & 5.43 & 1.543 & 0.229 \\
\hline Agility & 26.57 & 2.51 & 27.11 & 4.46 & 2.206 & 0.022 \\
\hline
\end{tabular}


Hasil uji-t berpasangan $\quad(\mathrm{p}<0,05)$ menunjukkan adanya peningkatan kemampuan fisik predominan (Daya Tahan Jantung Paru, Kekuatan Otot, Daya Ledak Otot, Kecepatan Reaksi, Kelincahan, Daya Tahan Otot, Dan Kelentukan) secara bermakna, akan tetapi kemampuan Pull, Push, Vertical Jump dan Flexibility menunjukkan kecenderungan peningkatan.

Terjadinya peningkatan daya tahan jantung paru yang diukur berdasarkan besarnya $\mathrm{VO}_{2}$ maks pada atlet Yong Moodo Yon Armed, oleh karena adanya pengaruh latihan terhadap peningkatan fungsi paru, volume dan komposisi darah, kemampuan jantung untuk memompa darah dan kemampuan otot untuk menggunakan oksigen ${ }^{32,34}$. Daya tahan jantung paru $\left(\mathrm{VO}_{2}\right.$ maks) seseorang dipengaruhi oleh genetik, usia, jenis kelamin, dan komposisi tubuh. Latihan fisik aerobik yang kontinue dengan kualitas, intensitas dan lamanya latihan yang terukur dan terprogram dengan baik akan menyebabkan peningkatan terhadap daya tahan jantung paru. Latihan aerobik yang terus menerus tentu saja akan berpengaruh terhadap fungsi dan adaptasi atau respon fisiologis dari paru, darah, pembuluh darah, otot, dan jantung.

Bentuk-bentuk latihan untuk meningkatkan daya tahan jantung paru antara lain : continoues run dengan waktu tempuh yang bervariasi; interval training dengan intensitas rendah dan sedang, bisa bentuk piramida (dari jarak terdekat ke jarak terjauh) atau piramida terbalik (dari jarak terjauh ke jarak terdekat); fartlek; cross country; fast jog dan renang jarak jauh. Latihan fast jog dengan intensitas $70 \%-80 \%$ Denyut Nadi Maksimal ${ }^{2,5}$.

Latihan untuk meningkatkan kekuatan otot pada atlet Yong Moodo Yon Armed dengan menggunakan latihan wight training yang terprogram baik akan menyebabkan perubahan secara fisiologis pada otot, yakni mengakibatkan hipertropi otot. Terjadinya hipertropi otot oleh karena adanya perubahan diameter dan volume otot, hal inilah yang menyebabkan peningkatan kekuatan otot. Selain itu pula didalam otot akan terjadi penambahan jumlah protein kontraktil, meningkatnya densitas kapiler, peningkatan filamen miosin dan peningkatan kekuatan jaringan ikat serta ligamen disekitar otot ${ }^{33,35,37}$. Semuanya ini menyebabkan peningkatan kekuatan otot. Selain itu peningkatan kekuatan otot setelah latihan menyebabkan peningkatan konsentrasi Kreatin Posfat, ATP, enzim glikolitik, meningkatnya enzim myokinase dan creatine phospokinase.

Bentuk latihan untuk meningkatkan kekuatan otot atlet Yong Moodo Yon Armed adalah dengan latihan beban atau weight training, yang dilakukan 2-3 x/minggu, dengan takaran 8-12 RM.3,4 Hal ini sejalan dengan prinsip overload training. Untuk mengukur kekuatan otot lengan atlet Yong Moodo Yon Armed adalah dengan hand dynamometer, sedangkan untuk kekuatan otot tungkai atlet Yong Moodo Yon Armed dengan leg dynamometer dan otot punggung atlet Yong Moodo Yon Armed yaitu back dynamometer. 
Secara umum, prinsip yang diaplikasikan pada pengembangan kekuatan otot berlaku untuk pengembangan daya tahan otot. Oleh karena itu, metode pelatihan kekuatan dapat digunakan pada pelatihan daya tahan otot dengan beberapa modifikasi sebagai berikut: mengurangi jumlah resistensi, meningkatkan kecepatan latihan, meningkatkan jumlah repetisi tiap set.

Untuk meningkatkan daya tahan otot atlet Yong Moodo Yon Armed diperlukan latihan fisik teratur, terukur, dan terprogram dengan memperhatikan kualitas dan kuantitas latihan. Adaptasi fisiologis terhadap latihan daya tahan otot atlet Yong Moodo Yon Armed biasanya dapat terbentuk setelah 6-12 minggu latihan.

Untuk mengukur daya tahan otot perut atlet Yong Moodo Yon Armed diukur dengan sit-ups, daya tahan otot lengan atlet Yong Moodo Yon Armed dan daya tahan otot bahu atlet Yong Moodo Yon Armed diukur dengan push-up, daya tahan otot tungkai atlet Yong Moodo Yon Armed diukur dengan squat-jumps.

Latihan untuk meningkatkan daya ledak otot atlet Yong Moodo Yon Armed merupakan salah satu dari komponen gerak pada atlet yang sangat penting untuk melakukan aktivitas yang sangat berat dan cepat. Oleh karena itu dapat menentukan seberapa kuat atlet dalam memukul, seberapa kuat atlet dapat menangkis, dan seberapa cepat atlet dapat menghindar.

Untuk mengukur daya ledak otot lengan dilakukan dengan Two Hand Medicine Ball dan untuk mengukur daya ledak otot tungkai dilakukan dengan Vertical Jump.
Latihan untuk meningkatkan kelentukan atlet Yong Moodo Yon Armed merupakan komponen fisik yang sangat diperlukan untuk atlet. Kelentukan dapat membantu meningkatkan kecepatan dan koordinasi gerak serta dapat membantu meningkatkan kelincahan. Oleh karena itu kelentukan diperlukan latihan secara khusus dan sesering mungkin, apalagi setelah latihan berat maka perlu latihan kelentukan terutama kelentukan pasif. Atlet yang mempunyai kelentukan tinggi tentu akan berbeda dengan atlet yang kaku dalam melaksanakan teknik gerak, kelentukan dapat mempengaruhi pada performance dan mengurangi resiko cedera otot.

Meningkatnya mobilitas dan memungkinkan gerakan menjadi lebih leluasa dan mudah, serta mampu menurunkan ketegangan otot yang berlebihan. Kelentukan dapat diukur dengan Flexometer guna mengukur kelentukan sendi panggul, tubuh, dan tendon hamstring.

Untuk meningkatkan kemampuan kecepatan reaksi atlet Yong Moodo Yon Armed maka dilakukan latihan dengan cara berlatih memindahkan benda dengan jarak kurang lebih 3 meter. Pindahkan benda itu dengan gerakan berlari bolak balik dengan kecepatan yang cukup dan semakin meningkat. Lakukan latihan ini semakin lama semakin meningkat sesuai dengan kemampuan diri masing-masing, Kedua Melatih kecepatan kedua lengan dengan cara berlatih lempar tangkap bola berpasangan dengan jarak 3 meter sebagaimana latihan pertama. Variasikan 
berpasangan dengan 3 atau 4 orang. Jika anda berlatih sendiri berlatihlah dengan dinding, pantulkan bola dengan jarak 1,5 meter. Pantulkan bola dengan lurus dan kombinasi berbentuk huruf $\mathrm{V}$, sehingga terjadi pergerakan badan ke kiri dan ke kanan.

Jus jambu biji merah diberikan dalam takaran 300 - $500 \mathrm{ml} /$ hari atau 2-3 buah ukuran sedang, takaran tersebut sudah mencakup kandungan gizi.8,13 memiliki potensi di bidang kesehatan khususnya kesehatan olahraga sebagai sumber senyawa antioksidan (vitamin $\mathrm{C}$, vitamin E, $\beta$-karoten, flavonoid, dan likopen) dan berperan sebagai fitonutrien.8,13 Vitamin $\mathrm{C}$ disebut antioksidan karena berfungsi sebagai donor elektron, sehingga dapat mencegah senyawa lain mengalami oksidasi. Saat vitamin C melepaskan elektron, ia menjadi radikal askorbil. Dibandingkan dengan radikal bebas lain, radikal askorbil ini relatif stabil dengan waktu paruh 10-15 detik dan tidak reaktif. Radikal bebas yang merugikan dapat berinteraksi dengan vitamin $\mathrm{C}$ sehingga radikal bebas yang merugikan tersebut mengalami reduksi dan vitamin $\mathrm{C}$ berubah menjadi radikal askorbil yang kurang reaktif. Proses reduksi radikal bebas reaktif menjadi senyawa yang kurang reaktif ini disebut free radical scavenging. Vitamin C merupakan free radical scavenging yang baik.

Vitamin E juga berfungsi mencegah penyakit hati, mengurangi kelelahan dan mengurangi PMS, membantu memperlambat penuaan karena oksidasi, mensuplai oksigen ke darah sampai dengan ke seluruh organ tubuh.24 Vitamin E juga menguatkan dinding pembuluh kapiler darah dan mencegah kerusakan sel darah merah akibat racun. Vitamin E juga membantu mencegah kerusakan otot. Vitamin E juga dikenal sebagai tokoferol, khususnya pada molekul alfa tokoferol.

Beta karoten merupakan salah satu dari 600 komponen karotenoid yang berperan dalam detoksifikasi berbagai bentuk radikal bebas.25,26 Sebagai figmen turunan, karotenoid bersifat larut dalam lemak dan berfungsi sebagai peredam singlet oksigen dan radikal bebas. Antioksidan tidak larut air ini menjaga integritas membran sel (membran sel otot) terhadap serangan oksidan, terutama melalui sifatnya yang dapat mengkelat radikal bebas oksigen singlet. Komponen karotenoid juga mampu menurunkan efek toksik dari senyawa oksigen reaktif. Sebagai antioksidan, flavonoid dapat menghambat penggumpalan keping-keping sel darah, dan juga menghambat pertumbuhan sel kanker.

Struktur likopen mempunyai banyak ikatan rangkap. Senyawa ini diketahui memiliki potensi antioksidan paling besar, dua kali lebih besar dibandingkan dengan $\beta$-karoten dan sepuluh kali lebih besar dibandingkan dengan vitamin E.12,29 


\section{KESIMPULAN}

Pengaruh Latihan Dengan Pemberian Jus

Psidium Guajava Dapat Meningkatkan

Komponen Fisik Predominan (Daya Tahan

Jantung Paru, Kekuatan Otot, Daya Ledak Otot,

Kecepatan Reaksi, Kelincahan, Daya Tahan

Otot, Dan Kelentukan) Atlet Yong Moodo Pada

Persiapan Pertandingan Antar Batalyon

\section{SARAN}

1. Disarankan bagi para pelatih dan atlet Yong Moodo serta para pembina olahraga agar melakukan latihan disertai dengan pemberian jus psidium guajava dalam meningkatkan komponen fisik predominan (daya tahan jantung paru, kekuatan otot, daya ledak otot, kecepatan reaksi, kelincahan, daya tahan otot, dan kelentukan) dan menurunkan kadar nitric oxide atlet Yong Moodo pada persiapan pertandingan antar batalyon

2. Untuk mengetahui pengaruh latihan dengan pemberian jus psidium guajava terhadap komponen fisik predominan (daya tahan jantung paru, kekuatan otot, daya ledak otot, kecepatan reaksi, kelincahan, daya tahan otot, dan kelentukan).

\section{DAFTAR PUSTAKA}

Foran. B. \& Pound, R. Complete Conditioning. Illinois: Human Kinetics; 2007

Bompa, T.O. Theory and methodology of training. 2 nd editon. NewYork: The Benyamin/ Cumming Publishing Company. 2009

PO Astrand, Rodahl K. Textbook of Work Physiology: Physiological Bases of Exercise. New York: McGraw Hill; 2003

Sujoto, JB. Teknik Oyama Karate Kihon Kata Kumite. Jakarta : PT. Elek Media Komputindo. 2006

Huang Z, Back LJG, Azizi F, et al. Shapiro DB. Nitric Oxide (NO) Binding To Oxygenerated Hemoglobin Under Physiological Conditions. Am J. Bhioc Biops Acta. 2001; 1568: 252 - 60.

Rahmat A, Mohd FZ and Zarida H. The effect of guava (Psidium Guajava) consumption on total antioxidant and lipid profile in normal make youth. Malays J. Agric Nutr. 2006:6

Padayatty, S. J., Katz, A., Wang, Y., et al. Vitamin C As An Antioxidant: Evaluation Of Its Role In Disease Prevention. J Am Coll Nutr, 2003 ; 22, 18-35.

$\mathrm{Li} \mathrm{Li}$ Ji. Free Radicals and Exercise ; Implications in Health and Fitness. Journal of Exercise Science and Fitness. . $2003 ; 1$ (1) : 15-22.

Watson, AW. Physical Fitness and Athletic Performances: AGuide for Students, Athletes and Coaches. New York: Longman Inc. 2003 